Sains Malaysiana 48(1)(2019): 61-68

http://dx.doi.org/10.17576/jsm-2019-4801-07

\title{
Effects of Organic Amendment on Soil Organic Carbon in Treated Soft Clay in Paddy Cultivation Area
}

(Kesan Bahan Pembaik Pulih Organik ke atas Karbon Organik Tanah dalam Tanah Jerlus Terawat di Kawasan Penanaman Padi)

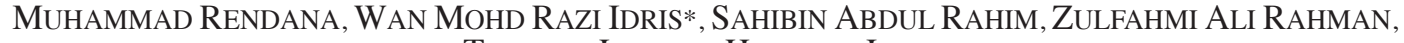 \\ TUKIMAT LIHAN \& HABIBAH JAMIL
}

\begin{abstract}
Soft clay soil has become a major problem in paddy cultivation area. Nearly half of the total paddy field in Kedah State, Malaysia cannot be utilized for paddy cultivation because of soft clay soil. The problem is related to the presence of weak hardpan structure that permits the soil to experience continuous wet condition. The soil also causes in the alteration of many processes soil organic carbon sequestration and turnover, but the main effect on the land is decrease in soil fertility. To investigate the effects of soft clay soil on soil organic carbon content, stock and change rate, the trial has been conducted in Alor Senibong paddy field area in Kedah, Malaysia examining the problematic paddy field that associated with soft clay soil problem. Hasil Tani Organic Compound (HTOC) was an organic soil amendment that used to enhance soil organic carbon in this study. Paddy field with the presence of soft clay soil showed a low soil organic carbon content and stock around $0.67 \%$ and $1.01 \mathrm{t} \cdot \mathrm{ha}^{-1}$, respectively (depth $\left.0-15 \mathrm{~cm}\right)$. The reduction of soil organic carbon content in soft clay soil was likely because of the waterlogged soil environment, the stability of soil aggregates and decline in humification process which then reduced soil organic carbon input. After being treated with HTOC, soil organic carbon content and carbon stock in soft clay soil have significantly increased by 0.67-3.14\% and 1.01-4.76 t.hat (depth 0-15 $\mathrm{cm})$, respectively, yielding a mean monthly carbon change rate of $4.36 \mathrm{~g} \mathrm{C} \mathrm{kg}^{-1} \cdot \mathrm{mth}^{-1}$ (depth $0-15 \mathrm{~cm}$ ). As whole, the succession of HTOC application to improve soil organic carbon content in this study could be employed in other paddy field areas that associated with soft clay soil problem.
\end{abstract}

Keywords: Organic amendment; soft clay soil; soil fertility; soil organic carbon

ABSTRAK

Tanah jerlus telah menjadi masalah utama di kawasan penanaman padi. Hampir separuh daripada jumlah sawah padi di Negeri Kedah, Malaysia tidak boleh digunakan untuk penanaman padi kerana tanah jerlus. Masalah ini adalah berkaitan dengan kewujudan struktur lapisan keras tanah lemah yang membolehkan tanah mengalami keadaan basah secara berterusan. Tanah jerlus juga menyebabkan perubahan banyak kepada proses penyerapan atau kehilangan karbon organik tanah, tetapi kesan utama pada tanah adalah penurunan kesuburan tanah. Untuk mengkaji kesan tanah jerlus pada kandungan karbon organik tanah, stok karbon tanah dan kadar perubahan kandungan karbon organik tanah, sebuah kajian telah dilakukan di kawasan sawah Alor Senibong, Kedah, Malaysia yang menghadapi masalah tanah jerlus. Sebatian Organik Hasil Tani (HTOC) adalah bahan pembaik pulih tanah yang digunakan dalam kajian ini untuk meningkatkan kandungan karbon organik dalam tanah. Plot sawah yang bermasalah tanah jerlus menunjukkan kandungan karbon organik tanah dan stok karbon yang rendah sekitar $0.67 \%$ dan $1.01 \mathrm{t} \cdot \mathrm{ha}^{-1}$ (kedalaman tanah 0-15 $\mathrm{cm}$ ). Pengurangan kandungan karbon organik tanah dalam tanah jerlus dijangkakan disebabkan oleh persekitaran tanah yang berair, kestabilan agregat tanah dan penurunan proses penghumusan yang kemudiannya mengurangkan input karbon organik tanah. Selepas dirawat dengan HTOC, kandungan karbon organik tanah dan stok karbon dalam tanah jerlus meningkat dengan ketara sebanyak 0.67-3.14\% dan 1.01-4.76 tha ${ }^{-1}$ (kedalaman tanah 0-15 cm), dengan

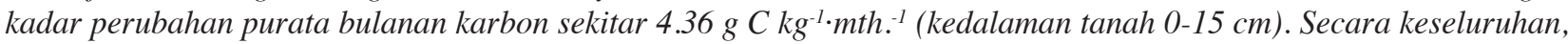
kejayaan aplikasi HTOC untuk meningkatkan kandungan karbon organik tanah dalam kajian ini boleh digunakan di kawasan sawah lain yang berkaitan dengan masalah jerlus.

Kata kunci: Bahan pembaik pulih organik; karbon organik tanah; kesuburan tanah; tanah jerlus

\section{INTRODUCTION}

Paddy fields are artificial wetlands, with cultivation under surface irrigation and nutrient management practices (Ping \& Wei 2013). Rice is the staple food for Malaysian, performing 3,000 tonnes of the rice production in 2016 (FAO 2016). Paddy cultivation is believed to be the most important sites for global carbon cycling. In paddy soils, soil organic carbon accumulation commonly occurs 
because of intensive rice production, inputs of high level of plant residues, coupled with their slowed decomposition under anaerobic conditions (Marrenjo et al. 2016). Soil organic carbon is a basic component of all agro-ecosystems and role as an essential link among various physical, chemical and biological properties in the soil (Maggie et al. 2018). The mechanism of soil organic carbon stabilization is related to occlusion into aggregates and phytoliths, as well as by interaction with iron oxides and clay minerals (Wissing et al.2013). Soil organic carbon content also acts to maintain a sustainable increase in rice production (Zhao et al. 2016). However, tillage, crop residue and nutrient management practices are common factors to influence soil organic carbon dynamic in paddy soils. Studies proposed that soil management practices, such as intensive tillage and crop residue burning or removal can contribute to soil organic carbon loss (Ghimire et al. 2015). In paddy field area, another factor which can affect the soil organic carbon dynamic is the presence of soft clay soil. This soil is characterized with very low compaction as indicated by the soil penetration resistance value of less than $0.40 \mathrm{MPa}$ (Azizul 2008). This is probably due to the weak hardpan layer that cannot support the surcharge load imposed by machinery equipment, especially during soil preparation and harvesting seasons. In Kedah, Malaysia, this problem has become a major issue and influenced the income of the paddy planters of that affected areas. The non-stop cultivation, climate and poor drainage system are several factors that caused soft clay soil problem in the paddy field area (Zulfahmi et al. 2017). Besides, some abandoned paddy fields that associated with soft clay soil problem become waterlogged area due to poor drainage, which then it can affect the carbon sequestration. Major processes influencing soil organic carbon dynamic in waterlogged soil environment of paddy field include changes in redox potential, soil $\mathrm{pH}$, reduction of carbon, nitrogen and sulfur (Fageria et al. 2011). Soil chemical changes under reduced environment and extremely limited oxygen supply in the floodwater system also considerably influence soil organic carbon content.

Numerous studies across climatic zones have reported soil carbon dynamic that occurred in the paddy field area (Peng et al. 2017; Watanabe et al. 2017). However, the most of studies only focused on the normal paddy soils. On the other hand, change of soil organic carbon in soft clay soil at the problematic paddy field has been rarely reported. The presence of soft clay soil in paddy field area will result in dramatic change in soil environment. Declining soil organic carbon due to the soft clay soil problem can decrease in soil fertility which then may be one of the most important reasons for rice yield stagnation. Therefore, improving soil fertility, especially soil organic carbon content is an important key in maintaining a sustainable increase in rice production (Murphy 2015). One of the common options to enhance the soil organic carbon is through organic soil amendments (Liu et al. 2016; Zhang et al. 2016). Hasil Tani Organic Compound (HTOC) is an alternative product that could potentially acts as soil amendment to increase soil organic carbon and soil quality. This is manufactured by using organic component consisting of wood residuals as well as humic acid and zeolite mineral in a specific ratio (Sahibin et al. 2016). Hence, this current study aimed to examine closely the effects of soft clay soil on soil organic carbon content and observed the change of soil organic carbon content after the application of HTOC product.

\section{MATERIALS AND METHODS}

\section{SITE DESCRIPTION}

The experimental paddy field was located in Alor Senibong, Langgar, Kedah, Malaysia (66'15.19'N and $100^{\circ} 27^{\prime} 55.74$ 'E) (Figure 1). This region had a tropical humid monsoon climate, with mean annual precipitation of $2,364 \mathrm{~mm}$ and mean annual temperature of $30^{\circ} \mathrm{C}$. The paddy soil was an acid sulphate soil that characterized with low $\mathrm{pH}$ because the presence of jarosite (sulfate mineral) in the subsoil. The studied soil was clay in texture with fine particles (clay + silt) about $80 \%$ that classified as Tualang Series (Paramananthan 1987). The clay minerals of soft soils are the basis of kaolinites. The layers in kaolinite are held together by fairly weak bonds as compared to illite and montmorillonite, thus make the soil is susceptible to disperse. This site has experienced with the presence of soft clay soil problem that caused the soil become less fertile and low rice yield with an average production of less than $2 \mathrm{t} \mathrm{ha}^{-1}$ season $^{-1}$. Paddy cultivation in this area applied the fertilizers and pesticides subsidized by Malaysian government.

\section{FIELD TRIAL}

The soil column with three replicates (30 $\mathrm{cm}$ depth) were collected at problematic soils (soft clay soil) and at normal soils within the paddy field area to measure soil organic carbon content and soil properties in May 2016, before plowing period and after applying HTOC product at the first harvest (September 2016). Plot size was about 1.5 ha. HTOC was applied after the first plowing activities using a portable sprayer with capacity of $200 \mathrm{~L}$ at rate of $0.20 \mathrm{t}$ HTOC ha-1 season ${ }^{-1}$. Rice variety MR219 was used in this study that was commonly planted by farmers throughout Peninsular Malaysia.

\section{SOIL ANALYSIS}

For soil analysis, soil samples were air-dried and passed through a $2 \mathrm{~mm}$ sieve before analyzing the physical and chemical properties. The visible pieces of organic material were removed before and after grinding. Soil organic carbon content was determined using CHNS instrument. The following laboratory works were carried out to determine paddy soil properties. Soil $\mathrm{pH}$ was analyzed by using distilled water based on 1:2.5 ratio of soil and water which then it was measured by $\mathrm{pH}$ meter WTW INOLAB Level 1 (Metson 1956). Electrical conductivity was extracted into saturated gypsum and measured by meter 


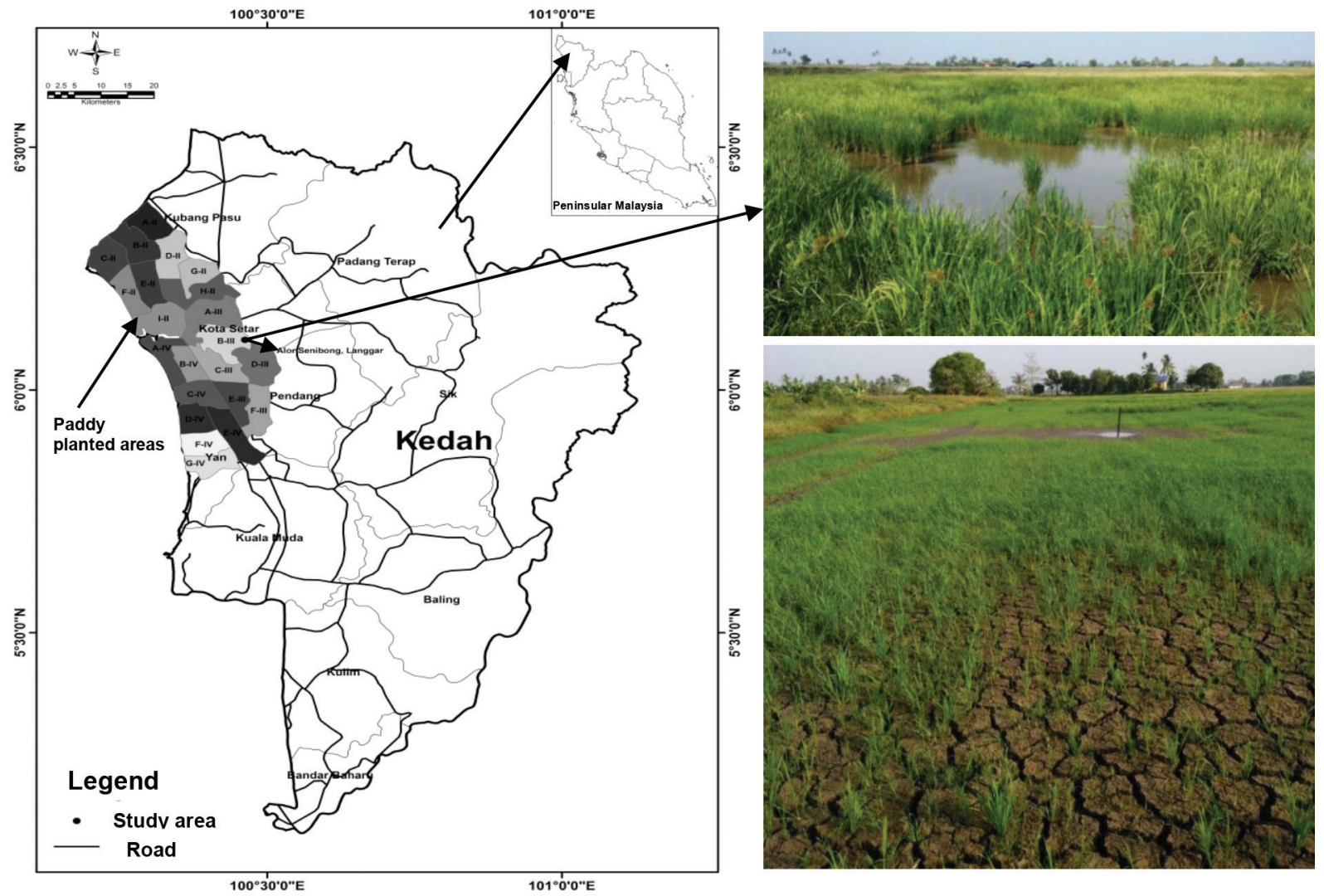

FIGURE 1. Location of the study area

conductivity device Model H 18819 Hanna (Massey \& Windsor 1967). Organic matter content was determined using the gravimetric method (Avery \& Bascomb 1982) and the hydraulic conductivity was determined using the falling head method (Kirkby 1980). The soil bulk density was determined using wax method (Russell \& Balcerek 1944). Total nitrogen was determined using Kjeldahl Method (Persson 2008). Humic acid content in the soil was extracted by suspending the soil overnight in $\mathrm{NaOH}$ $\left(0.5 \mathrm{~mol} \cdot \mathrm{l}^{-1}\right)$ solution and the supernatant was collected by centrifugation. The extract was then acidified up to $\mathrm{pH} 2.0$ using $6 \mathrm{~N} \mathrm{HCl}$. The residue was washed with $\mathrm{HCl}(0.5$ $\mathrm{mol} \cdot \mathrm{l}^{-1}$ ) solution and the washings and supernatants were combined for separating humic acid.

\section{CALCULATIONS}

Soil Organic Carbon Change Rate The rate of change in the soil organic carbon content was calculated as the difference in the soil organic carbon content under a given treatment across the study months, divided by the duration (months), as follows:

$$
\Delta \mathrm{C}_{\text {rate }}=\Delta \mathrm{C}_{\text {cont }} /\left(\mathrm{i}_{2}-\mathrm{i}_{1}\right)
$$

where $\Delta \mathrm{C}_{\text {rate }}$ is the rate of change in soil organic carbon content $\left(\mathrm{g} \mathrm{C} \cdot \mathrm{kg} \cdot \mathrm{mth}^{-1}\right)$; and $\mathrm{i}$ is the time of measurements (months); and $\Delta \mathrm{C}_{\text {cont }}$ is the difference in soil organic carbon content from month $\mathrm{i}_{2}$ to month $\mathrm{i}_{1}$.
Soil Carbon Stock Soil carbon stock in specific depth was calculated as follows:

$$
\mathrm{Cs}=\operatorname{conc}_{i} \times \mathrm{B}_{\mathrm{d}} \times \mathrm{H}
$$

where $\mathrm{Cs}$ is the soil organic carbon in specific depth $\left(\mathrm{t} \cdot \mathrm{ha}^{-1}\right)$; conc $_{\mathrm{i}}$ is the soil organic carbon content $\left(\mathrm{g} \cdot \mathrm{kg}^{-1}\right) ; \mathrm{B}_{\mathrm{d}}$ is the soil bulk density $\left(\mathrm{t} \cdot \mathrm{m}^{-3}\right)$; and $\mathrm{H}$ is the soil thickness $(0.30 \mathrm{~m})$.

\section{STATISTICAL ANALYSIS}

Data were analyzed and tabulated in IBM SPSS Statistic software version 21. Significant differences between the means were evaluated at the $95 \%$ confidence interval using independent sample t-test $(p<0.05)$. The relationships between the variables were evaluated using correlation analysis.

\section{RESULTS}

\section{SOIL ORGANIC CARBON AND BASIC PROPERTIES OF SOFT CLAY SOIL}

The soil analysis results from the soil samples of experimental paddy field were shown in Table 1 . The soil organic carbon content of soft clay soil taken from the experimental field was found low, it had about $0.67 \%$. The lowest soil organic carbon was observed in the topsoil and 
increased throughout the depth. Contrarily, the soil organic carbon was found a higher than soft clay soil with value of $2.96 \%$. The $\mathrm{pH}$ value of the soft clay soil was at 3.20 and it was slightly lower than normal soil. This low $\mathrm{pH}$ in this region was due to the presence of jarosite in the soil. To optimum production, paddy soil needed $\mathrm{pH}$ value around 5.5-6.5, hence the lime and soil amendment was applied to improve soil properties. Electrical conductivity of the soft clay soil and normal soil was low and salt-free with values of 2.07 and $2.11 \mathrm{mS} \cdot \mathrm{cm}^{-1}$, respectively. Hydraulic conductivity in the soft clay soil was a poor-drained at $0.19 \mathrm{~cm} \cdot \mathrm{hr}^{-1}$ while normal soil was a well-drained at 0.72 $\mathrm{cm} \cdot \mathrm{hr}^{-1}$. Soil organic carbon was highly positive correlated with hydraulic conductivity (Figure 2). The soil bulk density was found to be at the good level, which means they could provide structural support for water and solute movement as well as aeration. Organic matter content in the soft clay soil was low at around $1.36 \%$ while normal soil was moderate at $5.07 \%$. Total nitrogen in the soft clay soil was low at $0.13 \%$ while normal soil was moderate at $0.22 \%$. Humic acid content in the soft clay soil was found a lower than the normal soil (Table 1). This acid had a great importance in ensuring the occurrence of microbial decomposition of different organic substrates (Munawar \& Wanti 2016).

\section{SOIL CARBON STOCK}

Soil organic carbon and carbon stock dynamics at various depths in the experimental field were shown in Table 2.
Soil organic carbon and carbon stock in the soft clay soil exhibited lower values than normal soil. Soil organic carbon content was found the lowest at depth $0-15 \mathrm{~cm}$ with value of $0.67 \%$. Subsequently, it raised to $2.68 \%$ at depth $15-30 \mathrm{~cm}$. The lowest soil carbon stock was found around $1.01 \mathrm{t} \cdot \mathrm{ha}^{-1}$ at depth $0-15 \mathrm{~cm}$ and increased to 4.10 at depth $15-30 \mathrm{~cm}$. On the other hand, the normal soil exerted the highest soil carbon stock in this trial with value of $5.00 \mathrm{t} \cdot \mathrm{ha}$ ${ }^{1}$ at depth $0-15 \mathrm{~cm}$ and then increased to $5.24 \mathrm{t} \cdot \mathrm{ha}^{-1}$ at depth $15-30 \mathrm{~cm}$. There was a significant change for soil organic carbon and carbon stock in the soft clay soil and normal soil $(p<0.05$, Table 2$)$. This showed that the presence of soft clay soil significantly decreased soil organic carbon content in the soil as compared to normal soil. However, the soil bulk density would not change during cultivation period. This assumption was supported by constant soil bulk density throughout the depths between soft clay soil and normal soil in the experimental paddy field $(p>0.05$, Table 2). Moreover, this study found a positive correlation between the water stability soil aggregates and soil organic carbon (Figure 2).

\section{SOIL ORGANIC CARBON DYNAMIC BEFORE AND AFTER HTOC APPLICATION}

Soil organic carbon and carbon stock in the soft clay soil samples before and after being treated with HTOC product were shown in Table 3 . The application of HTOC significantly increased the soil organic carbon content by 0.67-3.14\% (depth 0-10 cm) and 2.68-2.84\% (depth 15$30 \mathrm{~cm}$ ) in September 2016 from the amount in May 2016.

TABLE 1. Basic soil properties in the topsoil $(0-15 \mathrm{~cm})$ of experimental field and paddy soils for rice cultivation in the tropical Asia

\begin{tabular}{lccc}
\hline Parameter & $\begin{array}{c}\text { Paddy field with soft } \\
\text { clay soil }^{1}\end{array}$ & $\begin{array}{c}\text { Paddy field with } \\
\text { normal soil }\end{array}$ & $\begin{array}{c}\text { Paddy soils for rice cultivation in } \\
\text { the tropical Asia }\end{array}$ \\
\hline $\mathrm{pH}$ & 3.20 & 3.27 & $5.5-6.5^{2}$ \\
Electrical conductivity $\left(\mathrm{mS} \cdot \mathrm{cm}^{-1}\right)$ & 2.07 & 2.11 & $<2.70^{3}$ \\
Bulk density $\left(\mathrm{g} \cdot \mathrm{cm}^{-3}\right)$ & 1.00 & 1.02 & $0.99-1.10^{4}$ \\
Hydraulic conductivity $\left(\mathrm{cm} \cdot \mathrm{hr}^{-1}\right)$ & 0.19 & 0.72 & $0.42-1.41^{5}$ \\
Organic matter $(\%)$ & 1.36 & 5.07 & $7-11^{4}$ \\
Soil organic carbon $(\%)$ & 0.67 & 2.96 & $2-3^{2}$ \\
Total nitrogen $(\%)$ & 0.13 & 0.22 & $0.2-0.3^{2}$ \\
Humic acid $(\%)$ & 0.05 & 0.21 & $0.13-0.33^{6}$ \\
\hline
\end{tabular}

${ }^{1}$ Measured in experimental field; ${ }^{2}$ (MARDI 2008); ${ }^{3}$ (MAFF 1970); ${ }^{4}$ (Aimrun et al. 2011); ${ }^{5}$ (USDA 1971); ${ }^{6}$ (Prabhat \& Pil 2014)

TABLE 2. Soil organic carbon and soil carbon stock dynamics at various depths in experimental field

\begin{tabular}{lcccccc}
\hline & \multicolumn{2}{c}{ Bulk density $\left(\mathrm{g} \cdot \mathrm{cm}^{-3}\right)$} & \multicolumn{2}{c}{ Soil organic carbon $(\%)$} & \multicolumn{2}{c}{ Soil carbon stock $\left(\mathrm{t} \cdot \mathrm{ha}^{-1}\right)$} \\
\cline { 2 - 7 } Field & $\begin{array}{l}0-15 \\
(\mathrm{~cm})\end{array}$ & $\begin{array}{c}15-30 \\
(\mathrm{~cm})\end{array}$ & $\begin{array}{c}0-15 \\
(\mathrm{~cm})\end{array}$ & $\begin{array}{c}15-30 \\
(\mathrm{~cm})\end{array}$ & $\begin{array}{c}0-15 \\
(\mathrm{~cm})\end{array}$ & $\begin{array}{c}15-30 \\
(\mathrm{~cm})\end{array}$ \\
\hline $\begin{array}{l}\text { Paddy field with } \\
\text { soft clay soil }\end{array}$ & $1.00 \pm 0.01^{\mathrm{a}}$ & $1.02 \pm 0.01^{\mathrm{a}}$ & $0.67 \pm 0.09^{\mathrm{b}}$ & $2.68 \pm 0.02^{\mathrm{b}}$ & $1.01 \pm 0.14^{\mathrm{b}}$ & $4.10 \pm 0.04^{\mathrm{b}}$ \\
$\begin{array}{l}\text { Paddy field with } \\
\text { normal soil }\end{array}$ & $1.02 \pm 0.01^{\mathrm{a}}$ & $1.01 \pm 0.01^{\mathrm{a}}$ & $3.27 \pm 0.32^{\mathrm{a}}$ & $3.46 \pm 0.02^{\mathrm{a}}$ & $5.00 \pm 0.49^{\mathrm{a}}$ & $5.24 \pm 0.03^{\mathrm{a}}$ \\
\hline
\end{tabular}

Different letters in a column mean significant differences at $5 \%$ level 
(a)

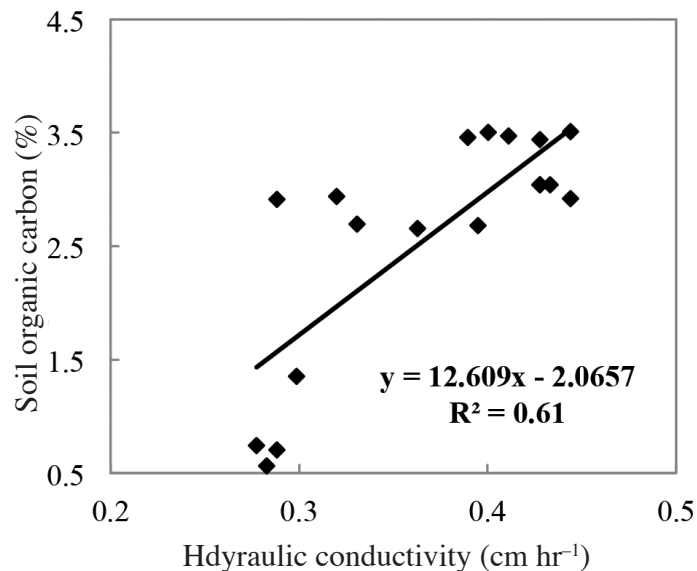

(b)

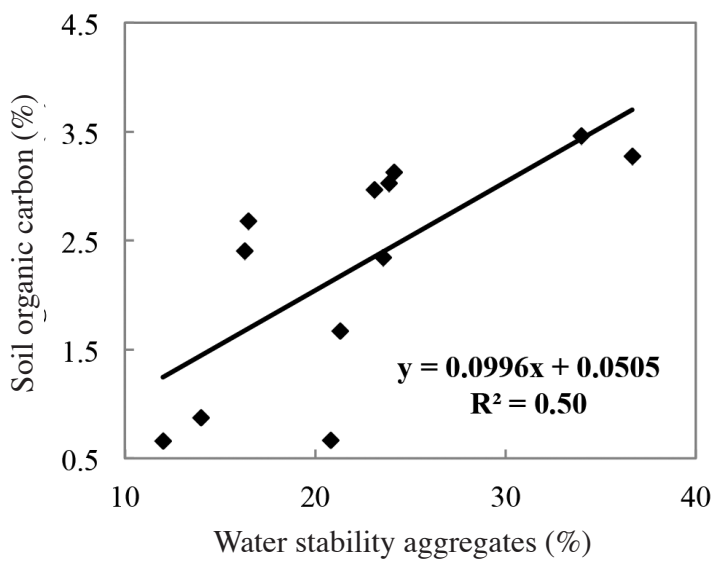

FIGURE 2. Relationship between soil organic carbon and hydraulic conductivity (a) and soil organic carbon and water stability aggregates (b)

While, soil carbon stock raised from the initial values by 1.01-4.76 t $\cdot \mathrm{ha}^{-1}$ (depth 0-10 $\mathrm{cm}$ ) and 4.10-4.39 $\mathrm{t} \cdot \mathrm{ha}^{-1}$ (depth $15-30 \mathrm{~cm}$ ). There was found a significant difference at $5 \%$ level for the soil organic carbon and carbon stock between the period of before applying HTOC and after applying HTOC $(p<0.05$, Table 3$)$. During the cultivation period (MaySeptember 2016), the addition of HTOC to the soil increased the change rate by $4.94 \mathrm{~g} \cdot \mathrm{kg}^{-1} \cdot \mathrm{mth}^{-1}$ in depth $0-10 \mathrm{~cm}$. On the contrary, the change rate in depth $15-30 \mathrm{~cm}$ was low at $0.32 \mathrm{~g} \cdot \mathrm{kg}^{-1} \cdot \mathrm{mth} \cdot{ }^{-1}$. Relative soil organic carbon content was positively correlated with humic acid content (Figure 3) This figure showed an increase in humic acid content and soil organic carbon as the quantity of HTOC added to soil.

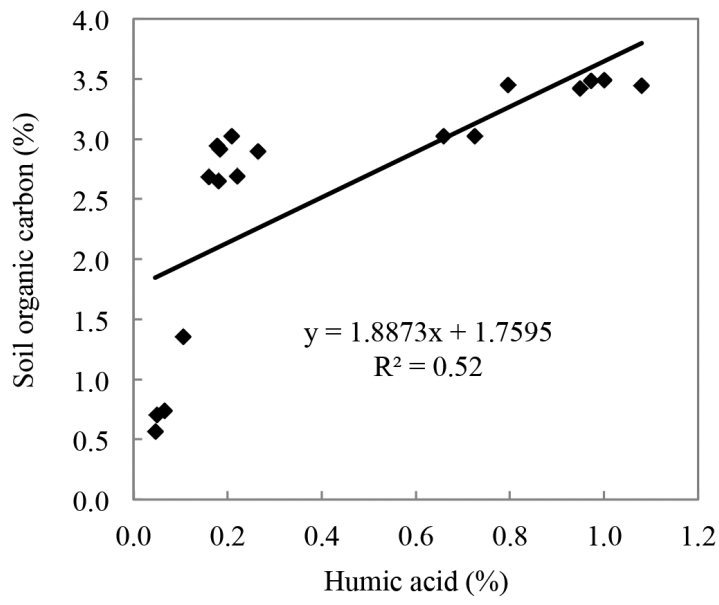

FIGURE 3. Relationship between soil organic carbon and humic acid content

\section{DISCUSSION}

\section{EFFECT OF SOFT CLAY SOIL ON SOIL ORGANIC CARBON}

The soil organic carbon and carbon stock value of soft clay soil in the experimental field was significantly lower than normal paddy soil. This value was at below the required level for rice production (MARDI 2002). The alteration the physical properties of soft clay soil affected the rate of soil organic carbon loss. The physical properties involved organic matter content and hydraulic conductivity. The result in this study showed that the soft clay soil had lower organic matter content as compared to normal soil. It was possible that the acidic nature of the soil may have limited the abundance of microbes and their ability to decompose biomass to release more carbon (Razi et al. 2017). Hydraulic conductivity described the ease with which water can move through soil pore spaces (Rodriguez et al. 2011). In the soft clay soil, the hydraulic conductivity value was very low resulted in waterlogged condition. This condition with extremely limited oxygen supply was considerably influence soil organic carbon (Xiao et al. 2017). The decrease in soil organic carbon content of

TABLE 3. Soil organic carbon and carbon stock in soft clay soil before and after being treated with HTOC product

\begin{tabular}{lcccc}
\hline \multirow{2}{*}{ Period } & \multicolumn{2}{c}{ Soil organic carbon $(\%)$} & \multicolumn{2}{c}{ Soil carbon stock $\left(\mathrm{t} \cdot \mathrm{ha} \mathrm{-}^{-1}\right)$} \\
\cline { 2 - 5 } & $0-15(\mathrm{~cm})$ & $15-30(\mathrm{~cm})$ & $0-15(\mathrm{~cm})$ & $15-30(\mathrm{~cm})$ \\
\hline $\begin{array}{l}\text { Before applying HTOC } \\
\text { (May 2016) }\end{array}$ & $0.67 \pm 0.09^{\mathrm{b}}$ & $2.68 \pm 0.02^{\mathrm{b}}$ & $1.01 \pm 0.14^{\mathrm{b}}$ & $4.10 \pm 0.04^{\mathrm{b}}$ \\
$\begin{array}{l}\text { After applying HTOC } \\
\text { (Sept 2016) }\end{array}$ & $3.14 \pm 0.10^{\mathrm{a}}$ & $2.84 \pm 0.03^{\mathrm{a}}$ & $4.76 \pm 0.15^{\mathrm{a}}$ & $4.39 \pm 0.04^{\mathrm{a}}$ \\
\hline
\end{tabular}

Different letters in a column mean significant differences at $5 \%$ level 
the soft clay soil was directly correlated with decrease in hydraulic conductivity value. Hence, the result of study showed that soft clay soil would give effect on the soil organic carbon content. According to our hypothesis, the soil organic carbon reduction was primarily due to the soft clay soil problem and not because of other factors, such as climate. To support our hypothesis, a study across the distinct climatic region (Nittya \& Sirintornthep 2011) was compared to this current study. Their output obtained the soil organic carbon level in paddy field without soft clay problem was found at good level. Moreover, soil organic carbon content in the topsoil from their study showed a higher value as compared to the soft clay soil sample in this current study. Typically, soil organic carbon decreased when the soil had low water stability of soil aggregates, whereas high water stability of soil aggregates could enhance the soil organic carbon accumulation (Eduardo et al. 2016). Both the studies (Meng et al. 2014; Wang et al. 2013) have found that the breakdown of water stable aggregates could lead to reduce soil organic carbon. The reduction may be attributable to the fact that soft clay soil was sodic soil, clay particles were less tightly bound to each other and soil aggregates easily dispersed when the soil became wet (Adnan et al. 2017). In addition, the decrease in soil organic carbon content of the soft clay soil was directly correlated with decrease in the water stability of soil aggregates value. Hence, the paddy field with soft clay soil tended containing soil organic carbon level near the minimum as compared to the other normal paddy soils. Another factor affecting soil organic carbon loss in the soft clay soil was the change of biological processes (Anlei et al. 2017). The presence of high moisture content permitted the soft clay soil to experiencing continuous wet condition. This condition caused to grow Cyperus plants around this area. Hence, carbon input into the paddy soil was from Cyperus roots. The greater amounts of Cyperus-root carbon and lower soil organic carbon content in the soft clay soil proposed that the conversion rate of Cyperus-root carbon to soil organic carbon was far lower than the carbon decomposition rate.

\section{EFFECT OF HTOC ON SOIL ORGANIC CARBON}

The use of HTOC in the experimental field affected soil organic carbon. Based on the result of previous studies the HTOC could raise organic carbon of soil and consequently decrease the excess moisture content of paddy soil (Sahibin et al. 2016). After being treated with HTOC, soil organic carbon and carbon stock content of soft clay soil significantly increased from the initial value. Soil organic carbon value was at the optimum range, where it was suitable for paddy cultivation about 2-3\% (MARDI 2002). This means that by adding HTOC product with standard rate into the land was sufficient to raise the soil organic carbon to above $2.50 \%$, which was within range of values required for paddy cultivation. The carbon sequestration in the soft clay soil was also rapidly increased after HTOC application. This showed soil organic carbon accumulation rates were clearly faster than the loss rates after HTOC application. The HTOC was enriched by organic matter in the form of humic acid that could supply source of carbon for metabolic reactions in the soil (Sahibin et al. 2016). The increase in soil organic carbon level in this study was directly correlated with increase in humic acid content. Other studies confirmed that the humification of organic substrates led to the condensation of carbon moiety and increased total carbon content in the soil (Claudia et al. 2013; Watanabe et al. 2007). Several studies showed that organic matter residues could enhance soil organic carbon level (Chivange et al. 2011; Liu et al. 2014; Peng et al. 2017). One of organic residues was rice straw compost (Watanabe et al. 2017), their result found that the application of rice straw compost in paddy soil could increase soil organic carbon to the optimum value. Our result agreed with those previous studies. However, at present, many farmers in this country simply burn rice straw in the field. Hence, the use of soil amendment product that manufactured from organic components like HTOC was needed for current agricultural practice.

\section{CONCLUSION}

The soft clay soil in the paddy field area had a low of soil organic carbon content $(0.67 \%)$ as compared to normal paddy soil $(2.96 \%)$. The waterlogged soil environment, the low of aggregate stability and humification process could reduce soil organic carbon in study area. After being treated with HTOC, soil organic carbon and carbon stock were rapidly increased by $0.67-3.14 \%$ and $1.01-4.76 \mathrm{t} \cdot \mathrm{ha}^{-1}$ of its initial content within one season of paddy cultivation period, respectively. The mean monthly rate of soil organic carbon change at this period was $4.94 \mathrm{~g} \mathrm{C} \mathrm{kg}^{-1} \cdot \mathrm{mth}^{-1}$. Therefore, the soft clay soil problem clearly carried a high risk of soil organic carbon loss and reduced the soil fertility in paddy field area. However, by treating the soft clay soil with HTOC product, soil organic carbon was able to be enhanced and maintained to range of values with high fertility index for rice production.

\section{ACKNOWLEDGEMENTS}

The authors wished to thank Universiti Kebangsaan Malaysia (UKM) and the Faculty of Science and Technology for providing the infrastructure to ensure the success of this research. This research was conducted with UKM research grant ETP-2015-003. The study was conducted in MADA region in collaboration with MADA and Green Frontier Technology Sdn Bhd.

\section{REFERENCES}

Adnan, N.S., Mohsin, T., Shahzad, B., Guozheng, Y., Shah, F., Saif, A., Muhammad, A.B., Shahbaz, A.T., Abdul, H. \& Biangkham, S. 2017. Soil compaction effects on soil health and crop productivity: An overview. Environ. Sci. Pollut. Res. 10: 1-13. 
Aimrun, W., Amin, M.S.M., Ezrin, M.H. \& Mastura, M. 2011. Paddy soil properties and yield characteristics based on apparent electrical conductivity zone delineation for a humid tropical rice farm. African Journal of Agricultural Research 6: 5339-5350

Anlei, C., Xiaoli, X., Tida, G., Haijun, H., Wei, W., Wenxue, W. \& Yakov, K. 2017. Rapid decrease of soil carbon after abandonment of subtropical paddy fields. Plant Soil 415: 203-214

Avery, B.W. \& Bascomb, C.L. 1982. Soil Survey Laboratory Methods, Soil Survey Technical Monograph. United Kingdom: Soil Survey of England and Wales.

Azizul, G. 2008. Soil hardpan improvement technique using vibrator subsoiler for rice mechanization farm. Buletin Teknologi Tanaman 5: 1-4.

Claudia, M.B.F.M., Etelvino, N., Tatiana, F.R. \& Michael, H.B.H. 2013. Soil organic matter: Chemical and physical characteristics and analytical methods. A Review. Current Organic Chemistry 17: 2985-2990.

Chivenge, P., Vanlauwe, B. \& Six, S. 2011. Does the combined application of organic and mineral nutrient sources influence maize productivity? A metaanalysis. Plant Soil 342: 1-30.

Eduardo, C.S.N., Marcos, G.P., Júlio, C.F.F. \& Thaís, A.C.N. 2016. Aggregate formation and soil organic matter under different vegetation types in Atlantic Forest from Southeastern Brazil. Semina: Ciencias Agrarias 37: 3927-3940.

Fageria, N.K., Moreira, A. \& Coelho,A.M. 2011. Yield and yield components of upland rice as influenced by nitrogen sources. Journal of Plant Nutrition 34: 361-370.

FAO. 2016. Statistical Databases. Food and Agriculture Organization of the United Nations. http://www.fao.org/ faostat/en/\#data.

Ghimire, R., Norton, J.B. \& Pendall, E. 2014. Alfalfa-grass biomass, soil organic carbon, and total nitrogen under different management approaches in an irrigated agroecosystem. Plant and Soil 374: 173-184.

Kirkby, M.J. 1980. Soil Erosion: Soil Loss Estimation. New York: John Wiley \& Sons.

Liu, C., Lu, M., Cui, J., Li, B. \& Fang, C.M. 2014. Effects of straw carbon input on carbon dynamics in agricultural soils: A meta-analysis. Glob. Chang. Biol. 20: 1366-1138.

Liu, X.W., Wang, H.Y., Zhou, J.M., Hu, F.Q., Zhu, D.J., Chen, Z.M. \& Liu, Y.Z. 2016. Effect of N fertilization pattern on rice yield, $\mathrm{N}$ use efficiency and fertilizer- $\mathrm{N}$ fate in the Yangtze River Basin, China. PLoS One 11: 1-6.

MAFF. 1970 Modern Farming and the Soil. Report of the Advisory Council on Soil Structure and Soil Fertility. HMSO, London.

Maggie, R.D., Bruno, J.R.A., Douglas, L.K., Keith, L.K., Marcelo, G. \& Dana,A. 2018. Review of soil organic carbon measurement protocols: A U.S. and Brazil comparison and recommendation. Sustainability 10: 1-20.

MARDI. 2002. Manual for Rice Cultivation. Serdang: Malaysian Agricultural Research and Development Institute.

Marrenjo, G.J., Pádua, E.J.D., Silva, C.A., Soares, P.C. \& Zinn, Y.L. 2016. Impacts of long-term cultivation of fooded rice in gley sols. Pesquisa Agropecuária Brasileira 51: 967-977.

Massey,D.M. \& Windsor, G.W. 1967. Report. Glasshouse Crops Res. Inst.p. 72.

Meng, Y.L., Qing, R.C., Yan, B.Q., Jing, L. \& Tao, C. 2014. Aggregation and soil organic carbon fractions under different land uses on the tableland of the Loess Plateau of China. Catena 115: 19-28.
Metson, A.J. 1956. Methods of Chemical Analysis for Soil Survey Samples. New Zealand: New Zealand Department of Scientific and Industrial Research.

Munawar, A. \& Wanti, M. 2016. Effect of humic acid on soil chemical and physical characteristics of embankment. MATEC Web of Conferences 58: 1-6.

Murphy, B.W. 2015. Impact of soil organic matter on soil properties-A review with emphasis on Australian soils. Soil Research 53: 605-635.

Nittaya, C. \& Sirintornthep, T. 2011. Variation of soil organic carbon stock in abandoned rice field managed by crop rotation. 3rd iLEAPS Science Conference GarmischPartenkirchen, 18-23 September, Germany.

Paramananthan, S. 1987. Field Legend for Soil Surveys in Malaysia. Serdang: UPM Press.

Peng, W., Zeng, Y., Qinghua, S. \& Shan, H. 2017. Responses of rice yield and the fate of fertilizer nitrogen to soil organic carbon. Plant Soil Environ. 63: 416-421.

Persson, J.A. 2008. Handbook for Kjeldahl Digestion. 4th ed Denmark: FOSS, DK-3400 Hilleroed.

Ping, Y. \& Wei, Z. 2013. The exploitation of rice paddy field and its ecological protection. Intelligent System Design and Engineering Applications (ISDEA), Third International Conference, 16-18 January, Hong Kong, China.

Prabhat, P. \& Pil, J.K. 2014. Fractionation and characterization of humic acids fromorganic amended rice paddy soils. Science of the Total Environment 466: 952-956.

Razi, W.M.I., Sahibin, A.R., Zulfahmi, A.R., Tukimat, L., Habibah, J., Rendana, M. \& Fazahar, M.N. 2017. Total organic carbon and stock carbon in the soil at paddy field area Alor Senibong, Langgar, Kedah, Malaysia. Proceedings of Geography and Environment. September 26-27.pp. 274-280.

Rodriguez, O.D., Guevara, H.J.P., Ruíz, C.R.G., Barrientos, J.H \& Shevnin, V. 2011. Determination of hydraulic conductivity and fines content in soils near an unlined irrigation canal in Guasave, Sinaloa, Mexico. Journal of Soil Science and Plant Nutrition 11: 13-31.

Russell, E.W. \& Balcerek, W. 1944. The determination of the volume and airspace of soil clods. J. Agric. Sci.34: 123-132.

Sahibin, A.R., Mohd Razi, W.I., Tukimat, L., Jamil, H., Rendana, M., Asmadi, I. \& Zulfahmi, A.R. 2016. Effects of Hasil Tani Organic Compound Product (HTOC) on the physicochemical properties of paddy soils in MADA. Proceeding of the Soil Science Conference of Malaysia. April 5-7. Terengganu. pp. 339-344.

USDA. 1971. Guide for Interpreting Engineering uses of Soils Washington, D.C: U.S. Government Printing Office.

Wang, W., Xie, X., Chen, A., Yin, C. \& Chen, W. 2013. Effects of long-term fertilization on soil carbon, nitrogen, phosphorus and rice yield. J. Plant Nutr. 36: 551-561.

Watanabe, K., Hong, M.L. \& Kazuyuki, N. 2017. Effects of the continuous application of rice straw compost and chemical fertilizer on soil carbon and available silicon under a double rice cropping system in the Mekong Delta, Vietnam. JARQ 51: 233-239.

Watanabe, T., Kimura, M. \& Asakawa, S. 2007. Dynamics of methanogenic archaeal communities based on rRNA analysis and their relation to methanogenic activity in Japanese paddy field soils. Soil Biol. Biochem. 39: 77-87.

Wissing, L., Kolbl, A., Hausler, W., Schad, P., Cao, Z.H. \& KogelKnabner, I. 2013. Management-induced organic carbon accumulation in paddy soils: The role of organo-mineral associations. Soil Tillage Res. 126: 60-71. 
Xiao, L.X., Wei, W., Wen, W.T. \& Ke, J.X. 2017. Waterlogging accelerates the loss of soil organic carbon from abandoned paddy felds in the hilly terrain in subtropical China. Scientific Reports 7: 1-6.

Zhao, Y.N., He, X.H., Huang, X.C., Zhang, Y.Q. \& Shi, X.J. 2016. Increasing soil organic matter enhances inherent soil productivity while offsetting fertilization effect under a rice cropping system. Sustainability 8: 879.

Zhang, X.B., Sun, N., Wu, L.H., Xu, M.G., Bingham, I.J. \& Li, Z.F. 2016. Effects of enhancing soil organic carbon sequestration in the topsoil by fertilization on crop productivity and stability: Evidence from long-term experiments with wheat-maize cropping systems in China. Science of the Total Environment 562: 247-259.

Zulfahmi, A.R., Sabturo, M.S.A., Idris, W.M.R., Lihan, T. \& Rendana, M. 2017. Effect of organic fertilizer on atterberg limit and strength of problematic clay soil. Proceedings of Geography and Environment. September 26-27. Perak. pp. 338-344.

Muhammad Rendana

Postgraduate Programme

Universitas Sriwijaya, 30139 Bukit Besar, Palembang

Indonesia

Wan Mohd Razi Idris* Zulfahmi Ali Rahman \& Tukimat Lihan School of Environmental and Natural Resource Sciences

Faculty of Science and Technology

Universiti Kebangsaan Malaysia

43600 UKM Bangi, Selangor Darul Ehsan

Malaysia
Sahibin Abdul Rahim

Environmental Sciences Programme

Faculty of Science and Natural Resources

Universiti Malaysia Sabah

88400 Kota Kinabalu, Sabah

Malaysia

Habibah Jamil

Geology Programme

Faculty of Science and Technology

Universiti Kebangsaan Malaysia

43600 UKM Bangi, Selangor Darul Ehsan

Malaysia

*Corresponding author; email: razi@ukm.edu.my

Received: 18 February 2018

Accepted: 10 August 2018 